уДК 37

DOI 10.21661/r-554010

Кошельченко А.С.

Организация работы по сенсорному развитию детей раннего дошкольного возраста посредством исследования наглядно-дидактического материала

\title{
Аннотация
}

Значение сенсорного развития в раннем возрасте трудно переоценить. Именно этот возраст наиболее благоприятен для совершенствования органов чувств, накопления представлений об окружающем мире. Сенсорное воспитание является задачей умственного, эстетического и физического воспитания. Полноценное сенсорное развитие может осуществляться лишь в процессе специально организованного сенсорного воспитания, когда у детей происходит целенаправленное формирование эталонных представлений о форме, цвете, величине, о свойствах и признаках разнообразных предметов и материалов, особенностях их положения в пространстве и др.

Ключевые слова: младшие дошкольники, сенсорные эталоны, наглядно-дидактический материал.

Koshelchenko A.S.

\section{Organisation of Work on Sensory Development of Children of Junior Preschool Age Through Examination of Visual and Didactic Material}

\section{Abstract}

The importance of sensory development in junior preschool age is difficult to overestimate. This age is most optimal for improvement of receptors, accumulation of notions about the world around us. Sensory development is the task of intellectual, aesthetic and physical education. Complete sensory development can occur only in the process of organised sensory education when the notions of form, colour, size and features of different objects and materials, peculiarities of their positioning in space and so on.

Keywords: junior preschoolers, sensory pattern, visual and didactic material.

$\mathrm{M}$ ы начали организационную работу с разработки дидактических игр, направленных на сенсорное развитие.

Формирующий этап длился шесть недель и проводился в виде игр-занятий, концентрированных по своему целевому содержанию, и систематизированных в своей последовательности.
На данном этапе эксперимента были разработаны и внедрены дидактические игры, направленные на развитие сенсорных способностей у детей младшего школьного возраста, а именно на развитие восприятия цвета, формы, величины (табл. 1).

Календарный план проведения дидактических игр представлен в таблице 2.

Таблица 1

Система дидактических игр для развития сенсорных эталонов младших дошкольников

\begin{tabular}{|l|l|}
\hline Сфера сенсорного развития & Комплекс дидактических игр \\
\hline Развитие восприятия формы & $\begin{array}{l}\text { «Башенка», «Найди такой же листик», «Собери башенку», «Найди } \\
\text { пару», «Укрась бабочку», «Спрячь мышку», «Почини одежду } \\
\text { зайчатам», «Разложи фигурки по местам», «Заплатки» }\end{array}$ \\
\hline $\begin{array}{l}\text { Развитие умения различать, чередовать, } \\
\text { группировать предметы по величине }\end{array}$ & $\begin{array}{l}\text { «Спрячь в ладошке», «Красавицы - Матрешки», «Мы фасолинки } \\
\text { берем и в бутылочку кладем», «Кошка и котята», «Большие } \\
\text { и маленькие мячики», «Золушка», «Кто, где живет?» }\end{array}$ \\
\hline $\begin{array}{l}\text { Развитие умения группировать предметы } \\
\text { по цвету }\end{array}$ & $\begin{array}{l}\text { «Разноцветные фишки», «Ленточки красивые, красные да синие», } \\
\text { «Найди такой же цветочек», «Светофор», «Найди такой же цвет», } \\
\text { «Карнавал» }\end{array}$ \\
\hline
\end{tabular}


Календарный план проведения дидактических игр

\begin{tabular}{|c|c|c|c|c|}
\hline Срок & Тема & Цель & Содержание & Приемы \\
\hline \multicolumn{5}{|c|}{ Октябрь, 1 неделя } \\
\hline Вторник & $\begin{array}{l}\text { «Спрячь } \\
\text { в ладошке» }\end{array}$ & $\begin{array}{l}\text { Развитие восприятия } \\
\text { величины }\end{array}$ & $\begin{array}{l}\text { Знакомство } \\
\text { с понятием величи- } \\
\text { ны. Обучение по- } \\
\text { нятиям «большой», } \\
\text { «маленький» }\end{array}$ & $\begin{array}{l}\text { Приемы. Сравнение и со- } \\
\text { поставление. Методы. На- } \\
\text { глядные (воспитатель берет } \\
\text { кубики в руку и прячет его } \\
\text { в ладони), словесные }\end{array}$ \\
\hline Среда & $\begin{array}{l}\text { «Цветные } \\
\text { капельки» }\end{array}$ & $\begin{array}{l}\text { Развитие восприятия } \\
\text { цвета }\end{array}$ & $\begin{array}{l}\text { Учить соотносить } \\
\text { предметы по цве- } \\
\text { ту, понимать слова } \\
\text { цвет, такой, не такой, } \\
\text { разные. }\end{array}$ & $\begin{array}{l}\text { Метод. Сравнение и сопо- } \\
\text { ставление. Приемы. } \\
\text { Словесные, педагог объяс- } \\
\text { няет, что нужно сделать: } \\
\text { «Опусти капельки в таре- } \\
\text { лочки соответствующ его } \\
\text { цвета». Средства. Тарелки } \\
\text { основных цветов, капельки, } \\
\text { вырезанные из цветного } \\
\text { картона }\end{array}$ \\
\hline Пятница & $\begin{array}{l}\text { «Красавицы - } \\
\text { Матрешки» }\end{array}$ & $\begin{array}{l}\text { Закрепить знания } \\
\text { о величине в ходе } \\
\text { практических дей- } \\
\text { ствий с игрушками } \\
\text { (использование ме- } \\
\text { тодов практического } \\
\text { примеривания) }\end{array}$ & $\begin{array}{l}\text { Продолжать учить } \\
\text { детей сопоставлять } \\
\text { предметы по вели- } \\
\text { чине, учить совме- } \\
\text { щать узор, ориен- } \\
\text { тироваться на слова } \\
\text { большая, аленькая, } \\
\text { меньше, еще мень- } \\
\text { ше, большая, еще } \\
\text { больше, открой, за- } \\
\text { крой, поставь в ряд }\end{array}$ & $\begin{array}{l}\text { Методы. Практическое } \\
\text { примеривание (наложение } \\
\text { одной матрешки, меньшей } \\
\text { размером, на другую, более } \\
\text { крупную. Сопоставление } \\
\text { (дети выбирают маленькую } \\
\text { матрешку, побольше). При- } \\
\text { емы. Песенка про веселых } \\
\text { матрешек.Средства. 4-х } \\
\text { местная матрешка (3 - рас- } \\
\text { крываются, 1 - нет) }\end{array}$ \\
\hline \multicolumn{5}{|c|}{ Октябрь, 2 неделя } \\
\hline Понедельник & «Башенка» & $\begin{array}{l}\text { Обучение цвету и } \\
\text { форме }\end{array}$ & $\begin{array}{l}\text { Знакомить с фор- } \\
\text { мой кольца, учить } \\
\text { сопоставлять ко- } \\
\text { лечки по величине, } \\
\text { ориентироваться } \\
\text { на слова большое, } \\
\text { маленькое, боль- } \\
\text { ше, меньше, такое, } \\
\text { не такое }\end{array}$ & $\begin{array}{l}\text { Методы. Словесные (воспи- } \\
\text { татель акцентирует на словах } \\
\text { «большой», «маленький», } \\
\text { «больше», «меньше». Сопо- } \\
\text { ставление (педагог показы- } \\
\text { вает, как сопоставлять колеч- } \\
\text { ки по величине). Приемы: } \\
\text { просьба произнести слова } \\
\text { «большой, больше, малень- } \\
\text { кий, меньше» Средства. Пи- } \\
\text { рамидка из 5-ти колец }\end{array}$ \\
\hline Среда & $\begin{array}{l}\text { «Разноцветные } \\
\text { фишки» }\end{array}$ & Обучение цвету & $\begin{array}{l}\text { Учить соотносить } \\
\text { предметы по цве- } \\
\text { ту, понимать слова } \\
\text { цвет, такой, не та- } \\
\text { кой, разные }\end{array}$ & $\begin{array}{l}\text { Приемы. Соотношение } \\
\text { (учить детей соотносить } \\
\text { фишки по цвету). Словес- } \\
\text { ные (педагог просит детей } \\
\text { повторить слова «цвет, та- } \\
\text { кой, разные», просит детей: } \\
\text { «Разложи те фишки в миски } \\
\text { соответствующего цвета». } \\
\text { Средства. Миски и фишки } \\
\text { соответствующего цвета } \\
\text { (красный, желтый, синй) }\end{array}$ \\
\hline
\end{tabular}




\begin{tabular}{|c|c|c|c|c|}
\hline Пятница & «Найденыш» & Обучение величине & $\begin{array}{l}\text { Учит детей соот- } \\
\text { носить размеры } \\
\text { «большой- малень- } \\
\text { кий», понятиям } \\
\text { «такой - не такой» }\end{array}$ & $\begin{array}{l}\text { Методы. Соотношение и } \\
\text { сравнение. Словесные (объ- } \\
\text { яснение детям задач, просьба } \\
\text { повторить слова «большой, } \\
\text { маленький». Прием - игро- } \\
\text { вая ситуация. Воспитатель } \\
\text { рассказывает детям о том, что } \\
\text { детки животных путешество- } \\
\text { вал и по лесу и заблудились, } \\
\text { помоги каждого вернуть сво- } \\
\text { ей маме. Средства. Парные } \\
\text { фигурки животных (большие } \\
\text { и маленькие): лиса и лисенок, } \\
\text { зайчиха и зайчонок и т. д. }\end{array}$ \\
\hline \multicolumn{5}{|c|}{ Октябрь, 3 неделя } \\
\hline Понедельник & $\begin{array}{l}\text { «Найди такой } \\
\text { же цвет» }\end{array}$ & Обучение цвету & $\begin{array}{l}\text { Дать ребенку фигур- } \\
\text { ку определенного } \\
\text { цвета, предложить } \\
\text { пройти по группе и } \\
\text { найти предметы та- } \\
\text { кого же цвета }\end{array}$ & $\begin{array}{l}\text { Методы. Сопоставление. } \\
\text { Выполнение поручений. } \\
\text { Приемы. Показ с называ- } \\
\text { нием. Педагог сначала сам } \\
\text { прошел по группе, нашел } \\
\text { одну фигурку, показал и } \\
\text { назвал ее. Средства. Фи- } \\
\text { гурки разных цветов }\end{array}$ \\
\hline Среда & «Золушка» & Обучение величине & $\begin{array}{l}\text { Высыпать ребенку } \\
\text { пуговицы разной } \\
\text { величины и пред- } \\
\text { ложить рассорти- } \\
\text { ровать их на боль- } \\
\text { шие и маленькие }\end{array}$ & $\begin{array}{l}\text { Методы. Соотношение и } \\
\text { сравнение. Прием. Показ } \\
\text { образца и рассматривание } \\
\text { рыбок в аквариуме. Сред- } \\
\text { ства. Рыбки из картона, от- } \\
\text { дельно вырезанные плав- } \\
\text { нички и хвостики }\end{array}$ \\
\hline Пятница & $\begin{array}{l}\text { «Наведи поря- } \\
\text { док» }\end{array}$ & $\begin{array}{l}\text { Учит детей опреде- } \\
\text { лять и запоминать ге- } \\
\text { ометрические формы }\end{array}$ & $\begin{array}{l}\text { Разобрать геоме- } \\
\text { трические тела и } \\
\text { называть их. В одну } \\
\text { коробку склады- } \\
\text { вать треугольники, } \\
\text { в другую - кубы, в } \\
\text { третью - шары }\end{array}$ & $\begin{array}{l}\text { Методы. Показ с называни- } \\
\text { ем. Воспитатель начинает } \\
\text { разбирать одно геометри- } \\
\text { ческое тело и называет его. } \\
\text { Словесный. Педагог про- } \\
\text { сит детей повторить назва- } \\
\text { ние геометрических форм. } \\
\text { Средства. Набор геометри- } \\
\text { ческих тел }\end{array}$ \\
\hline \multicolumn{5}{|c|}{ Октябрь, 4 неделя } \\
\hline Понедельник & $\begin{array}{l}\text { «Кто где жи- } \\
\text { вет?» }\end{array}$ & $\begin{array}{l}\text { Развивает представ- } \\
\text { ление о животном } \\
\text { мире, понятия «боль- } \\
\text { шой- маленький» }\end{array}$ & $\begin{array}{l}\text { Ребенок должен } \\
\text { помочь найти ка- } \\
\text { ждому животному } \\
\text { свой домик }\end{array}$ & $\begin{array}{l}\text { Методы. Совместные дей- } \\
\text { ствия воспитателя и ре- } \\
\text { бенка. Педагог участвует в } \\
\text { дидактической игре вместе } \\
\text { с детьми. Прием. Чтение } \\
\text { сказки «Заюшкина избуш- } \\
\text { ка», после чего педагог } \\
\text { предлагает найти домик для } \\
\text { зверей. Средства. Домики }\end{array}$ \\
\hline Среда & $\begin{array}{l}\text { «Аквариумные } \\
\text { рыбки» }\end{array}$ & $\begin{array}{l}\text { Развивает представ- } \\
\text { ление о величине и } \\
\text { цвете }\end{array}$ & $\begin{array}{l}\text { В танце рыбки по- } \\
\text { теряли свои плав- } \\
\text { нички и хвостики. } \\
\text { Ребенок } \\
\text { подобрать д рыбен } \\
\text { плавничок соответ- } \\
\text { ствующего размера } \\
\text { и цвета }\end{array}$ & $\begin{array}{l}\text { Методы. Соотношение и } \\
\text { сравнение. Прием. Показ } \\
\text { образца и рассматривание } \\
\text { рыбок в аквариуме. Сред- } \\
\text { ства. Рыбки из картона, от- } \\
\text { дельно вырезанные плав- } \\
\text { нички и хвостики }\end{array}$ \\
\hline
\end{tabular}




\begin{tabular}{|c|c|c|c|c|}
\hline Пятница & $\begin{array}{l}\text { «Наведи поря- } \\
\text { док» }\end{array}$ & $\begin{array}{l}\text { Учит детей опреде- } \\
\text { лять и запоминать ге- } \\
\text { ометрические формы }\end{array}$ & $\begin{array}{l}\text { Разобрать rеоме- } \\
\text { трические } \\
\text { и нелазывать их. В } \\
\text { одну коробку скла- } \\
\text { дывать треуголь- } \\
\text { ники, в другую } \\
\text { - кубы, в третью - } \\
\text { шары }\end{array}$ & $\begin{array}{l}\text { Методы. Показ с называни- } \\
\text { ем. Воспитатель начинает } \\
\text { разбирать одно геометри- } \\
\text { ческое тело и называет его. } \\
\text { Словесный. Педагог про- } \\
\text { сит детей повторить назва- } \\
\text { ние геометрических форм. } \\
\text { Средства. Набор геометри- } \\
\text { ческих тел }\end{array}$ \\
\hline \multicolumn{5}{|c|}{ Октябрь, 5 неделя } \\
\hline Понедельник & $\begin{array}{l}\text { «Спрячь мыш- } \\
\text { ку» }\end{array}$ & Обучение форме & 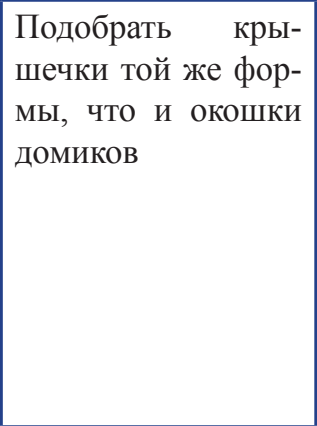 & $\begin{array}{l}\text { Методы. Сопоставление } \\
\text { и сравнение. Прием. Уча- } \\
\text { стие педагога в игре вместе } \\
\text { с детьми. Средства. Силу- } \\
\text { эты домиков, сделанные } \\
\text { из картона. В окошках до- } \\
\text { миков нарисованы мышки. } \\
\text { Окошки на домиках разной } \\
\text { формы: круглые, овальные, } \\
\text { квадратные, треугольные }\end{array}$ \\
\hline Среда & $\begin{array}{l}\text { «Почини оде- } \\
\text { жду зайчатам» }\end{array}$ & $\begin{array}{l}\text { Обучение детей } \\
\text { различать цвета и } \\
\text { использовать назва- } \\
\text { ния цветов в речи. } \\
\text { Закреплять умение } \\
\text { распознавать геоме- } \\
\text { трические фигуры и } \\
\text { называть их }\end{array}$ & \begin{tabular}{|l|} 
Дети подбирают \\
заплатки для одеж- \\
ды зайчат, в соот- \\
ветствие с формой
\end{tabular} & $\begin{array}{l}\text { Методы. Сравнение и со- } \\
\text { поставление. Словесный. } \\
\text { Дети по просьбе педагога } \\
\text { отвечают на вопросы: на } \\
\text { что похожи дырочки на } \\
\text { юбочках }\end{array}$ \\
\hline Четверг & «Знайка» & Обучает детей форме & $\begin{array}{l}\text { Дети помогают } \\
\text { Знайке определить, } \\
\text { из чего можно по- } \\
\text { строить воздуш- } \\
\text { ный шар }\end{array}$ & $\begin{array}{l}\text { Методы. Наглядные (иллю- } \\
\text { страции с воздушными ша- } \\
\text { рами). Словесные (объясне- } \\
\text { ния). Показ с называнием }\end{array}$ \\
\hline \multicolumn{5}{|c|}{ Ноябрь, 1 неделя } \\
\hline Вторник & «Светофор» & Обучение цвету & $\begin{array}{l}\text { Дети раскручива- } \\
\text { ют и закручивают } \\
\text { пробки от пластико- } \\
\text { вых бутылок к гор- } \\
\text { лышкам бутылок } \\
\text { такого же цвета }\end{array}$ & $\begin{array}{l}\text { Методы. Показ с называни- } \\
\text { ем. Прием. Чтение сказки } \\
\text { про светофор }\end{array}$ \\
\hline Среда & $\begin{array}{l}\text { «Разложи фигу- } \\
\text { ры по местам!» }\end{array}$ & $\begin{array}{l}\text { Учит детей подби- } \\
\text { рать нужные формы } \\
\text { разными методами. }\end{array}$ & $\begin{array}{l}\text { Раздать детям по } \\
\text { одной фигурке и } \\
\text { предложите по оче- } \\
\text { реди найти место } \\
\text { для каждой из них }\end{array}$ & $\begin{array}{l}\text { Методы. Показ с называ- } \\
\text { нием. Приемы. Совместная } \\
\text { деятельность }\end{array}$ \\
\hline Пятница & $\begin{array}{l}\text { «Веселая } \\
\text { рыбалка» }\end{array}$ & $\begin{array}{l}\text { Закрепление знаний } \\
\text { о цвете, развитие мо- } \\
\text { торики. }\end{array}$ & $\begin{array}{l}\text { Дети должны пой- } \\
\text { мать рыбки цвета } \\
\text { своей удочки }\end{array}$ & $\begin{array}{l}\text { Методы. Показ с называни- } \\
\text { ем. Педагог первый пока- } \\
\text { зывает, как нужно ловить } \\
\text { рыбок и называет цвет } \\
\text { рыбки. Прием. Песенка о } \\
\text { веселой рыбалке }\end{array}$ \\
\hline
\end{tabular}

Дети с интересом выполняли предложенные им задания. За время проведения работы был установлен положительный, эмоционально-психологический контакт с испытуемыми. 


\section{Литература}

1. Артемова Л.В. Мир в дидактических играх дошкольников: кн. для воспитателей дет. сада и родителей / Л.В. Артемова. - М.: Наука, 2002. - 96 с.

2. Балашова Э.В. Особенности формирования сенсорных эталонов у младших дошкольников посредствам игр в юнгианской песочнице / Э.В. Балашова, Ю.М. Васина // Научно-методический электронный журнал «Концепт». - 2016. - Т.15. - С. 601-605.

3. Венгер Л.А. Воспитание сенсорной культуры ребенка от рождения до 6 лет: кн. Для воспитателя детского сада/ Л.А. Венгер, Э.Г. Пилюгина, Н.Б. Венгер; под ред. Л.А. Венгера. - М.: Просвещение, 1998. - 144 с.

4. Венгер Л.А. Дидактические игры и упражнения по сенсорному воспитанию дошкольников: Пособие для воспитателей детского сада / Л.А. Венгер, Э.Г. Пилюгина, 3.Н. Максимова, Л.И. Сысуева; под ред. Л.А. Венгера. - М.: Просвещение, 1997. - 110 с.

\section{References}

1. Artemova, L. V. (2002). Mir v didakticheskikh igrakh doshkol'nikov: kn. dlia vospitatelei det. sada i roditelei., 96. M.: Nauka.

2. Balashova, E. V., \& Vasina, Iu. M. (2016). Osobennosti formirovaniia sensornykh etalonov u mladshikh doshkol'nikov posredstvam igr v iungianskoi pesochnitse. Nauchno-metodicheskii elektronnyi zhurnal "Kontsept", T.15, 601-605.

3. Venger, L. A., Venger, L. A., \& Piliugina, E. G. (1998). Vospitanie sensornoi kul'tury rebenka ot rozhdeniia do 6 let: kn. Dlia vospitatelia detskogo sada., 144. Venger;; M.: Prosveshchenie.

4. Venger, L. A., Venger, L. A., Piliugina, E. G., \& Maksimova, Z. N. (1997). Didakticheskie igry i uprazhneniia po sensornomu vospitaniiu doshkol'nikov: Posobie dlia vospitatelei detskogo sada., 110. Sysueva;; M.: Prosveshchenie. 